\title{
Identification of antifungal principle in the solvent extract of an endophytic fungus Chaetomium globosum from Withania somnifera
}

\author{
Susheel Kumar ${ }^{1}$, Nutan Kaushik ${ }^{2^{*}}$ and Peter Proksch ${ }^{3}$
}

\begin{abstract}
Extracts of Chaetomium globosum EF18, isolated as endophytic fungus from Withania somnifera, were found effective against Sclerotinia sclerotiorum. Ethyl acetate and methanol extracts were more effective than hexane extract showing $>80 \%$ growth inhibition. Bioactive compound (antibiotic Sch 210971, m/z 445 and $\lambda_{\max } 290$ ) having antifungal activity against $S$. sclerotiorum has been isolated in pure form from the ethyl acetate extract following bioassay guided fractionation. Apart from this compound other fractions of polar to medium polarity were also found effective. Fraction no. VIII from VLC (Vacuum liquid chromatography) column of ethyl acetate extract was most active having $\mid C_{50}$ value $35.4 \mu \mathrm{g} / \mathrm{ml}$.
\end{abstract}

Keywords: Chaetomium globosum, Endophyte, Withania somnifera, Antifungal, Sclerotinia

\section{Introduction}

The need for new and useful compounds to provide protection and relief to crop plants from pests and thereby sustenance of food production for human consumption is ever growing. Plant diseases have been causing devastating effects on crop plants and human life since the human civilization evolved (Agrios 2005). To combat such diseases, safer and greener chemicals have to be developed because conventional chemicals are posing greater threat to ecology and biodiversity and also causing ill effects to human health. Microbes and their compounds are emerging as alternative strategies for pest control (Montesinos 2003).

Many endophytic fungi and their metabolites have been reported to have insecticidal and fungicidal activity (Kumar et al. 2008). In our effort to isolate bioactive endophytic fungi, we isolated various endophytic fungi from Withania somnifera, among which Chaetomium globosum EF18 showed good activity against Sclerotinia sclerotiorum, Fusarium oxysporum and Rhizoctonia solani (Kumar et al., communicated paper). S. sclerotiorum is non-specific and omnivorous pathogen causing

\footnotetext{
* Correspondence: kaushikn@teri.res.in

${ }^{2}$ The Energy and Resources Institute (TERI), Habitat Center, Lodhi Road, New Delhi 110003, India

Full list of author information is available at the end of the article
}

diseases to plants belonging to 75 families, 278 genera, and 408 species (Boland and Hall 1994). Some of the major crops affected by $S$. sclerotiorum are brassicas, potato, chickpea, pea, sunflower, beans, carrot, lettuce, soybean, kiwifruit and grapes. Although the most common disease caused by S. sclerotiorum is white mould, yet cottony rot, watery soft rot, stem rot, drop, crown rot, blossom blight are also of common occurrence in crop plants causing yield loss up to $100 \%$ (Purdy 1979). 1.5 million Tones of yield reduction due to Sclerotinia infection in soybean have been reported in US during 2004 (Wrather and Koenning 2006). This paper describes the isolation of active metabolites of endophytic fungus through bioassay mediated fractionation using VLC, Column chromatography and preparative HPLC. Bioactivity was tested against $S$. sclerotiorum during the experimentation.

\section{Results}

Ethyl acetate, methanol (a portion of EtoAc extract was partitioned between methanol and hexane and then assayed to see if polarity has major effect on antifungal activity) and butanol extracts of endophytic fungus C. globosum were tested at $250 \mu \mathrm{g} / \mathrm{ml}$ and $500 \mu \mathrm{g} / \mathrm{ml}$ against S. sclerotiorum. Methanol extract showed 76.58\% mycelial growth inhibition (GI) at $500 \mu \mathrm{g} / \mathrm{ml}$ on $4^{\text {th }}$ day, 


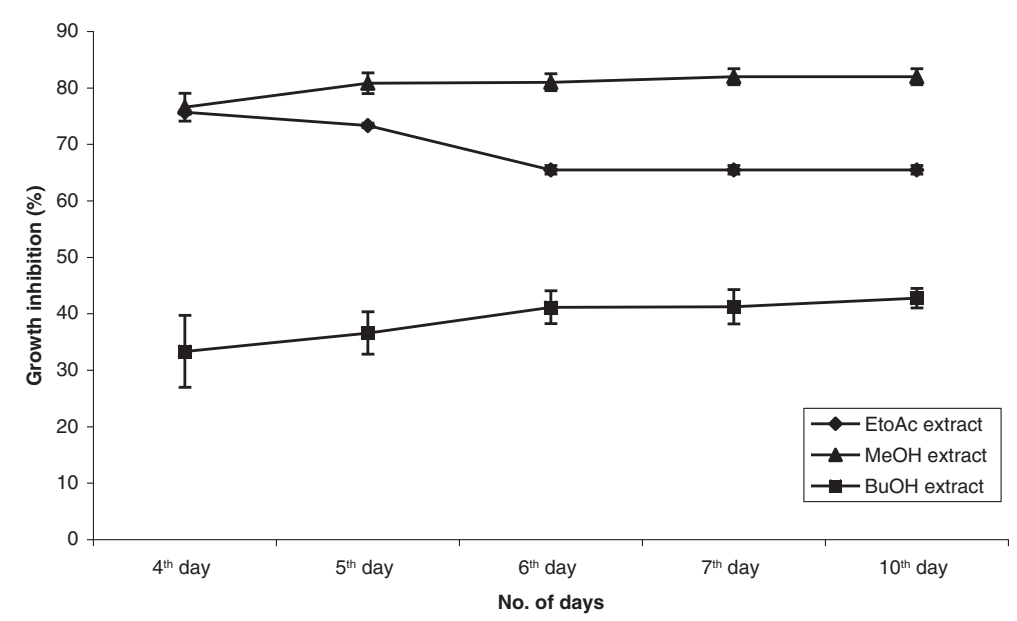

Figure 1 Effect of different extracts of Chaetomium globosum isolate EF18 against plant pathogenic fungi, Sclerotinia sclerotiorum $(\mathrm{CD} 0.05=6.864, \mathrm{CD} 0.01=9.261)$.

which further increased to $80.83 \%$ on $5^{\text {th }}$ day. Ethyl acetate extract was effective at $500 \mu \mathrm{g} / \mathrm{ml}$ having $75.68 \%$ growth inhibition on $4^{\text {th }}$ day. No significant difference was observed in the growth inhibition caused by ethyl acetate extract and methanol extract on $4^{\text {th }}$ day. Butanol extract was least effective showing $33.32 \%$ growth inhibition at $500 \mu \mathrm{g} / \mathrm{ml}$ on $4^{\text {th }}$ day. Graphical representation of GI over no. of days is given in Figure 1.

Ethyl acetate extract was further fractionated by VLC on silica gel. On the basis of HPLC and LC-MS analysis it was observed that all the VLC fractions were mixtures of many compounds. When tested for their bioactivity, fraction WSL-2E_VIII exhibited maximum mycelial growth inhibition of $95.9 \%, 83.7 \%$ and $75.6 \%$ at 500 $\mu \mathrm{g} / \mathrm{ml}, 200 \mu \mathrm{g} / \mathrm{ml}$ and $100 \mu \mathrm{g} / \mathrm{ml}$ respectively (Table 1 ). Fraction WSL-2E_VI, WSL-2E_VII, WSL-2E_IX and WSL-2E_X were statistically at par and caused more than $80 \%$ growth inhibition at $500 \mu \mathrm{g} / \mathrm{ml}$. Fraction IV and $\mathrm{V}$ exhibited least growth inhibition, $\sim 70 \%$ at 500 $\mu \mathrm{g} / \mathrm{ml}$, among all the fractions. Figure 2 shows growth inhibition caused by these fractions at different concentrations. $\mathrm{IC}_{50}$ values were calculated for these fractions and are provided in Table 2, which shows that lowest $\mathrm{IC}_{50}$ of $40.57 \mu \mathrm{g} / \mathrm{ml}$ and $35.4 \mu \mathrm{g} / \mathrm{ml}$ on $4^{\text {th }}$ and $5^{\text {th }}$ day respectively was observed in fraction no. VIII. Chi-square values and regression equation have also been provided in the Table 2. Fraction no. IX stands next to fraction VIII showing $\mathrm{IC}_{50}$ value of $80.14 \mu \mathrm{g} / \mathrm{ml}$ on $5^{\text {th }}$ day of observation.

The VLC fractions VI- X showing activity against $S$. sclerotiorum were having a common peak at RT 42.342.4 minutes (from Waters HPLC) (Figure 3). Correlation of chemical analysis and bioassay results, it is apparent that the compound eluting at RT 42.5 is responsible for the antifungal activity. As depicted in the Table 3, increased concentration- corresponds to increased area of the peak - of this compound in the fraction was prime cause of increased bioactivity of the fraction. Table 4 shows the regression model and correlation between increasing concentration of active compound in the fraction and bioactivity of fraction. Correlation coefficient ( $r$ ) of 0.86 was calculated between the \% area of the compound in the HPLC chromatogram and biological activity at $100 \mu \mathrm{g} / \mathrm{ml}$, which says that statistically $86 \%$ of the activity in these fractions is due to the compound and rest $14 \%$ is due to the unexplained reason. LC-MS analysis suggested the molecular weight of the compound associated with peak (RT 33.78 in LC-MS) as $445\left(\mathrm{~m} / \mathrm{z}^{+} 446\right.$ and $\mathrm{m} / \mathrm{z}^{-} 444$ ) and UV maxima 226 and $288 \mathrm{~nm}$ (as presented in

Table 1 Effect of different fractions obtained from vacuum liquid chromatography of ethyl acetate extract of Chaetomium globosum EF18 on growth of Sclerotinia sclerotiorum

\begin{tabular}{lllll}
\hline SI no. & Fractions & \multicolumn{3}{c}{ Growth inhibition (\%) on $\mathbf{5}^{\text {th }}$ day } \\
\cline { 3 - 5 } & & $\mathbf{1 0 0} \boldsymbol{\mu \mathbf { g } / \mathbf { m l }}$ & $\mathbf{2 0 0} \boldsymbol{\mu g} \mathbf{m l}$ & $\mathbf{5 0 0} \boldsymbol{\mu} \mathbf{g} \mathbf{m l}$ \\
\hline 1 & WSL 2E IV & $18.8 \pm 4.8$ & $43.9 \pm 5.4$ & $70.2 \pm 8.5$ \\
2 & WSL 2E V & $12.6 \pm 6.8$ & $39.6 \pm 1.7$ & $70.8 \pm 4.4$ \\
3 & WSL 2E VI & $21.6 \pm 1.0$ & $32.5 \pm 5.1$ & $81.6 \pm 2.4$ \\
4 & WSL 2E VII & $9.0 \pm 3.4$ & $61.9 \pm 7.5$ & $82.4 \pm 1.4$ \\
5 & WSL 2E VIII & $75.6 \pm 5.7$ & $83.7 \pm 1.6$ & $95.9 \pm 0.8$ \\
6 & WSL 2E IX & $56.0 \pm 8.5$ & $66.7 \pm 5.7$ & $84.5 \pm 0.8$ \\
7 & WSL 2E X & $25.2 \pm 6.4$ & $52.8 \pm 26.2$ & $90.2 \pm 1.4$ \\
\hline
\end{tabular}

Coefficient of variation $=25.38 \%$.

LSD-10.461 (0.05), 13.748 (0.01); $p \leq 0.05$. 


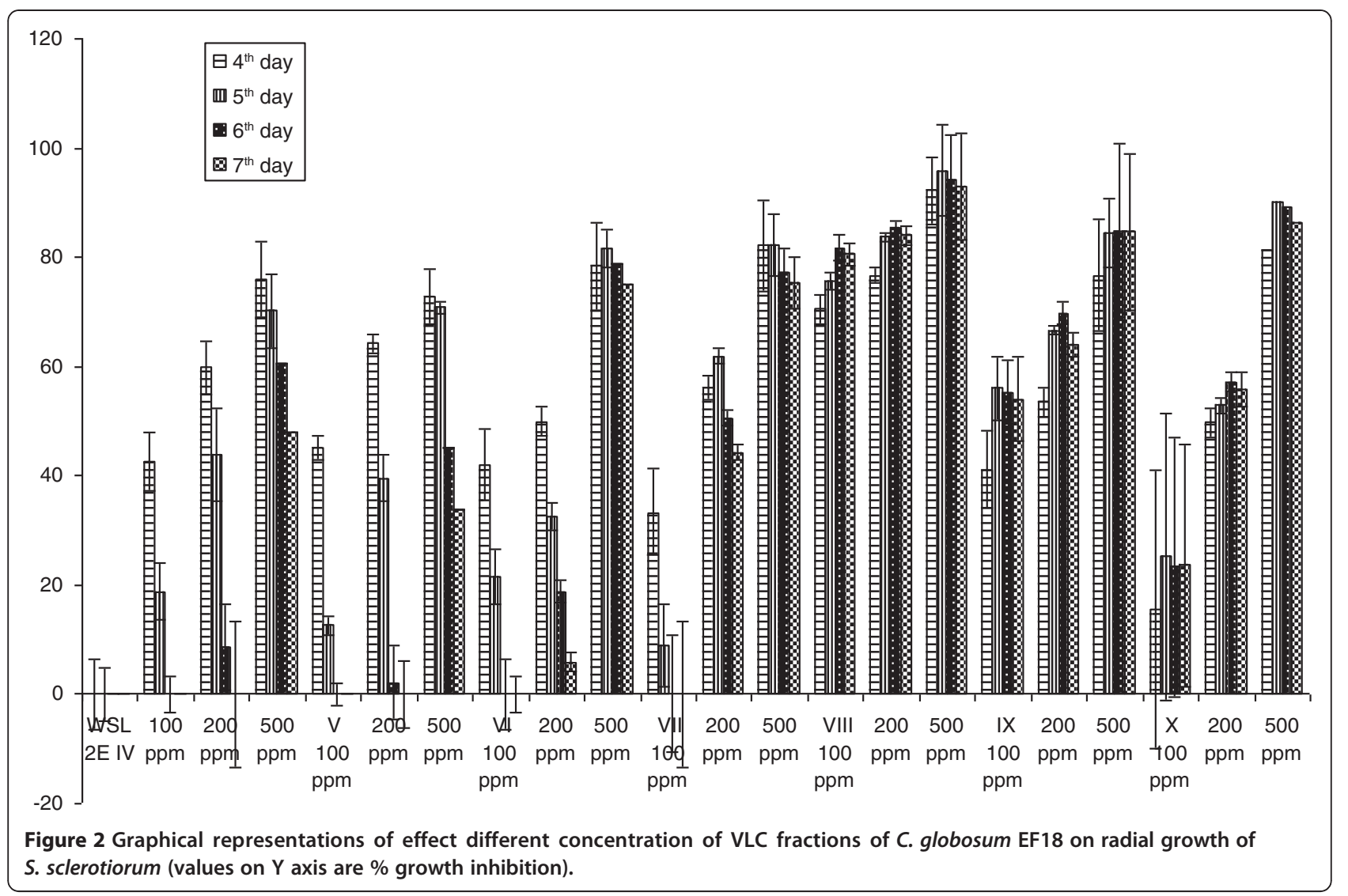

Figures 4, 5 and 6). Figure 7 shows the plate photograph of growth inhibition in Sclerotinia sclerotiorum due to the toxicant present in VLC fractions VIII, IX and X.

WSL-2E_VI _I_S1 fraction was subjected to preparative HPLC to obtain pure compound 'A', which was further analyzed by NMR spectroscopy. Comparative analysis of NMR and MASS revealed that compound 'A' is similar to Antibiotic Sch $210971\left(\mathrm{~m} / \mathrm{z} 445\right.$ and $\lambda_{\max }$ 290) (Figure 8), which has previously been isolated from C. globosum by Yang et al. (2006). In the finding by Yang et al. molecular weight of the isolated compound was $445 \mathrm{Da}$ and showed the protonated molecular ion at $\mathrm{m} / \mathrm{z}^{+} 446$ similar to the compound isolated by us. Also UV absorption of Sch 210971 at 220 and 295 was near to that of our compound i.e. 226 and 288.

\section{Discussion}

Hexane extract of C. globosum has been reported as antifungal against S. sclerotiorum and Botrytis cineria (Nakashina et al. 1991). However we find polar extract

Table $2 \mathrm{IC}_{50}(\mu \mathrm{g} / \mathrm{ml})$ values for VLC fractions of C. globosum EF18 tested against S. sclerotiorum

\begin{tabular}{|c|c|c|c|c|c|c|c|}
\hline \multirow[t]{2}{*}{ SI no. } & \multirow{2}{*}{$\begin{array}{l}\text { Extract } \\
\text { fraction }\end{array}$} & \multicolumn{3}{|c|}{$4^{\text {th }}$ day } & \multicolumn{3}{|c|}{$5^{\text {th }}$ day } \\
\hline & & $\overline{I C}$ & $x^{2}$ & Regression equation & $\mathrm{IC}_{50}$ & $x^{2}$ & Regression equation \\
\hline 1 & WSL 2E IV & 135.43 & 0.115 & $Y=2.711+1.272 X$ & 260.31 & 0.577 & $Y=4.818+1.995 X$ \\
\hline 2 & WSL 2E V & 114.71 & 1.189 & $Y=2.132+1.035 X$ & 281.95 & 0.841 & $Y=5.803+2.368 X$ \\
\hline 3 & WSL 2E VI & 158.74 & 2.037 & $Y=3.132+1.423 X$ & 243.86 & 5.635 & $Y=5.895+2.469 X$ \\
\hline 4 & WSL 2E VII & 166.84 & 0.001 & $Y=4.292+1.931 X$ & 209.56 & 14.76 & $Y=7.104+3.061 X$ \\
\hline 5 & WSL 2E VIII & 40.57 & 1.165 & $Y=1.97+1.225 X$ & 35.4 & 0.696 & $Y=2.228+1.438 X$ \\
\hline 6 & WSL 2E IX & 155.26 & 0.399 & $Y=3.008+1.373 X$ & 80.14 & 0.333 & $Y=2.351+1.235 X$ \\
\hline 7 & WSL 2E X & 220.44 & 1.301 & $Y=6.302+2.689 X$ & 179.31 & 0.414 & $Y=6.307+2.799 X$ \\
\hline
\end{tabular}




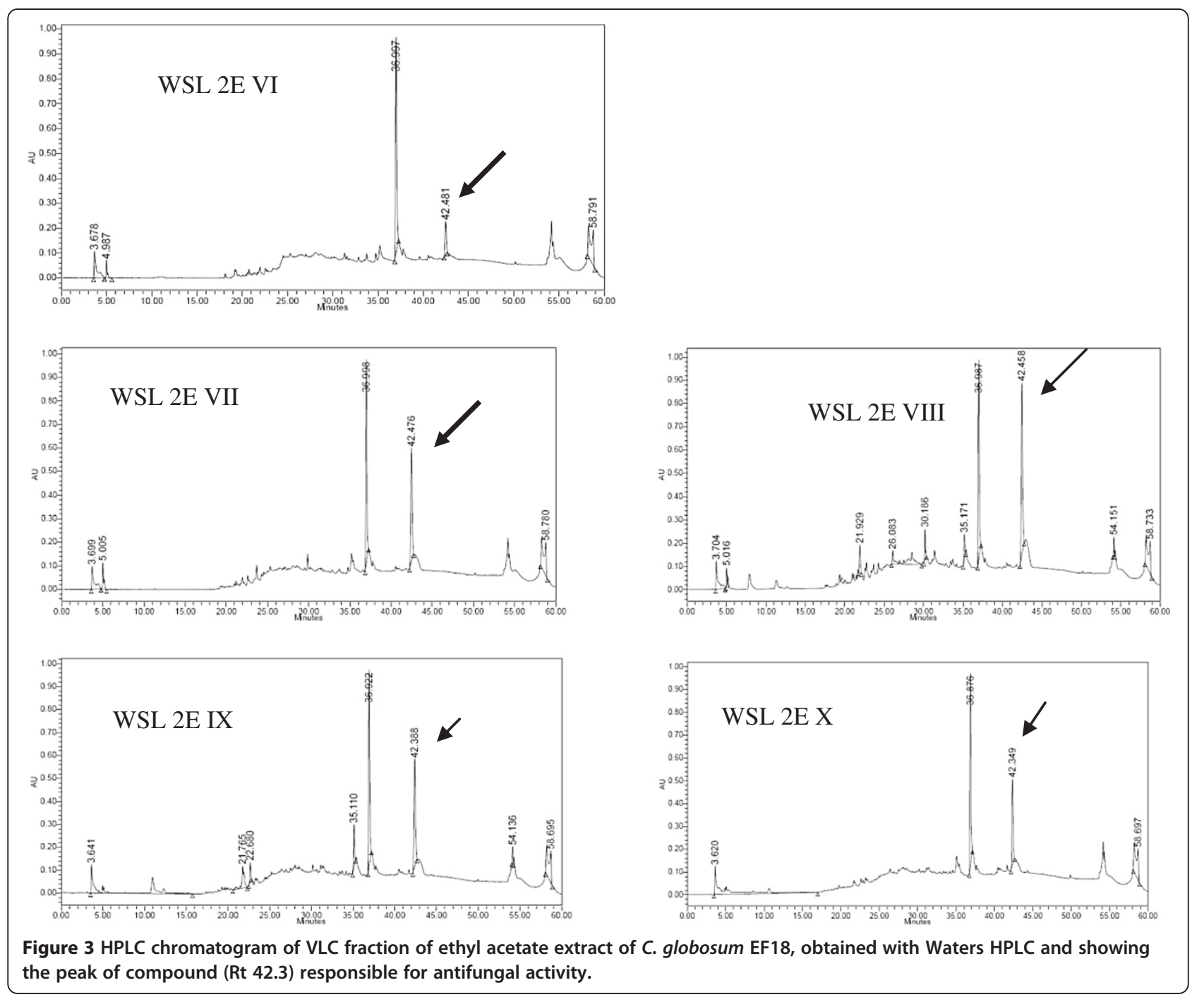

Table 3 Effect of increasing concentration of antibiotic sch210971 on GI property of VLC fractions against S. sclerotiorum

\begin{tabular}{|c|c|c|c|c|}
\hline \multirow{2}{*}{$\begin{array}{l}\text { Fraction } \\
\text { no. }\end{array}$} & \multirow{2}{*}{$\begin{array}{l}\text { \% Peak area } \\
\text { at }{ }^{*} \mathrm{Rt} 42.4 \mathrm{~min} \\
\left(\lambda_{\max } 288 \mathrm{~nm}\right)\end{array}$} & \multicolumn{3}{|c|}{ Growth inhibition (\%) } \\
\hline & & $100 \mu \mathrm{g} / \mathrm{ml}$ & $200 \mu \mathrm{g} / \mathrm{ml}$ & $500 \mu \mathrm{g} / \mathrm{ml}$ \\
\hline WSL 2E IV & - & 0.0 & 0.0 & 47.84 \\
\hline WSL 2E V & - & 0.0 & 0.0 & 33.72 \\
\hline WSL 2E VI & 8.88 & 0.0 & 3.92 & 74.90 \\
\hline WSL 2E VII & 27.6 & 0.0 & 44.31 & 75.29 \\
\hline WSL 2E VIII & 30.34 & 76.4 & 82.63 & 88.80 \\
\hline WSL 2E IX & 20.00 & 55.19 & 64.70 & 84.87 \\
\hline WSL 2E X & 18.48 & 21.57 & 55.74 & 86.55 \\
\hline
\end{tabular}

*This Rt (from Waters HPLC, C-18) corresponds to Rt 34.1 (from Dionex HPLC) of above chromatogram. viz. methanol and ethyl acetate were more active than hexane extract against S. sclerotiorum. Antibiotic Sch 210971 has been previously reported as chemokine receptor CCR-5 inhibitor (Yang et al. 2006); however this is the first report of antifungal activity of this compound. HPLC has been utilized for the first time in our study in finding out the principle component of C. globosum responsible for antifungal activity. Previously chaetomugilin $\mathrm{D}$, together with three known metabolites, chaetomugilin $\mathrm{A}$, chaetoglobosins $\mathrm{A}$ and $\mathrm{C}$ have been isolated by a bioassay-guided fractionation from the EtOAc extract of the cultures of C. globosum. Chaetomugilin D also reported to have antifungal activity against Mucor miehei (Qin et al. 2009). C. globosum an endophyte to a medicinal plant Curcuma wenyujin has yielded chaetoglobosin $\mathrm{X}$, which showed broad antifungal activity (Wang et al. 2012). Zhang et al. (2013) have also isolated 
Table 4 Correlation coefficient and regression model between \% peak area of sch210971 in different VLC fractions and their growth inhibition property against $S$. sclerotiorum

\begin{tabular}{|c|c|c|c|}
\hline Fraction no. & $\begin{array}{l}\text { \% Peak area at Rt } 42.4 \mathrm{~min} \\
\left(\lambda_{\max } 288 \mathrm{~nm}\right)\end{array}$ & $\begin{array}{l}\% \text { Growth inhibition } \\
\text { at } 100 \mu \mathrm{g} / \mathrm{ml}\end{array}$ & $\begin{array}{l}\% \text { Growth inhibition } \\
\text { at } 200 \mu \mathrm{g} / \mathrm{ml}\end{array}$ \\
\hline$\overline{\text { WSL 2E VIII }}$ & 30.34 & 76.4 & 82.63 \\
\hline WSL 2E IX & 20.00 & 55.19 & 64.70 \\
\hline WSL 2E X & 18.48 & 21.57 & 55.74 \\
\hline \multicolumn{2}{|c|}{ Regression Model } & $\begin{array}{l}\% \text { Gl }=-33.469+3.684 X \\
\% \text { Peak area } \pm 19.952\end{array}$ & $\begin{array}{l}\% \mathrm{Gl}=20.194+2.070 \times \\
\% \text { Peak area } \pm 4.14\end{array}$ \\
\hline \multicolumn{2}{|c|}{ Coefficient of determination (R) } & 0.740 & 0.954 \\
\hline \multicolumn{2}{|c|}{ Coefficient of correlation (r) } & 0.860 & 0.976 \\
\hline
\end{tabular}

chaetoglobosins $\mathrm{A}$ and $\mathrm{C}$ from $\mathrm{C}$. globosum and they found that chaetoglobosin A is having antifungal activity against Setosphaeria turcica, causal agent of northern corn leaf blight. Two other antifungal substances viz. chaetoviridins A and B have been purified from culture broth of C. globosum isolated from barnyard grass. Chaetoviridin A exhibited higher antifungal activity with $80 \%$ reduction in disease development at $62.5 \mu \mathrm{g} / \mathrm{ml}$ concentration against rice blast and wheat leaf rust and 50\% control of late blight of tomato at $125 \mu \mathrm{g} / \mathrm{ml}$ (Park et al. 2005), however purified fraction isolated in our experiment has $\mathrm{IC}_{50}$ value of $35.4 \mu \mathrm{g} / \mathrm{ml}$. In present study we have found that Antibiotic Sch 210971 can be used as marker for antifungal activity against S. sclerotiorum.

Role of C. globosum in biological control has been well documented and commercial formulation has also been developed (Soytong et al. 2001). Culture filtrate of C. globosum has been reported to successfully inhibit the mycelial growth of Pythium ultimum in In vitro and pot culture experiments. Chaetomin has been the principle compound responsible for this antifungal activity
(Di-Pietro et al. 1992). Cell wall degradation caused by beta-glucanases and carboxymethyl cellulases is one of the possible modes of action of C. globosum against P. ultimum (Inglis and Kawchuk 2002). Mode of action of Antibiotic Sch 210971 needs to be studied further. Antibiotic Sch 210971 enriched fraction can be formulated as antifungal biopesticide.

\section{Materials and methods}

HPLC was performed with Chromeleon Ver 6.3 program; Dionex P580A LPG Pump; Photo Diode Array (PDA) Detector UVD 340S detector; ASI-100T Autosampler; STH 585 Column Thermostat; Eurospher 100C18, Knauer column. HPLC of extracts was also performed on Waters HPLC system with Autosampler, 717 plus; PDA 2996 detector; System controller 600 and Empower2 software with polar gradient method. The samples were analyzed on a Phenomenex column $(250 \times$ $4.60 \mathrm{~mm}, 5 \mu$ ) using mobile phase acetonitrile: water (HPLC grade). Preparative HPLC was done with Varian prepstar 218 pump; Microsorb 60-8 C18 column with

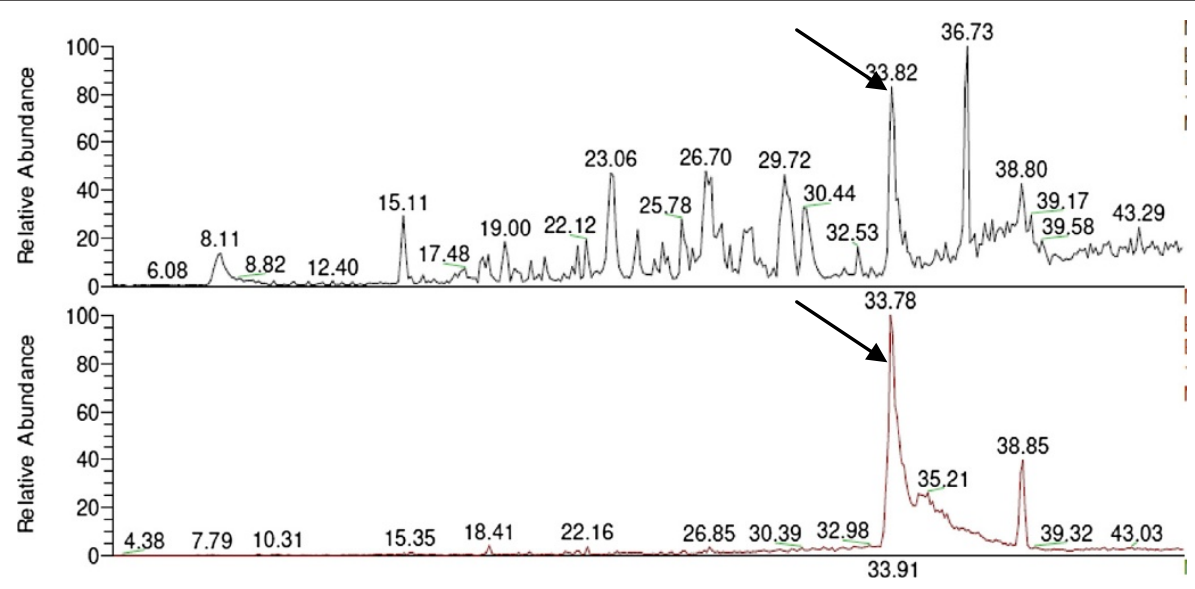

Figure 4 LC-MS chromatogram of purified fraction (WSL 2E VI_I_S1) obtained from preparative HPLC. 


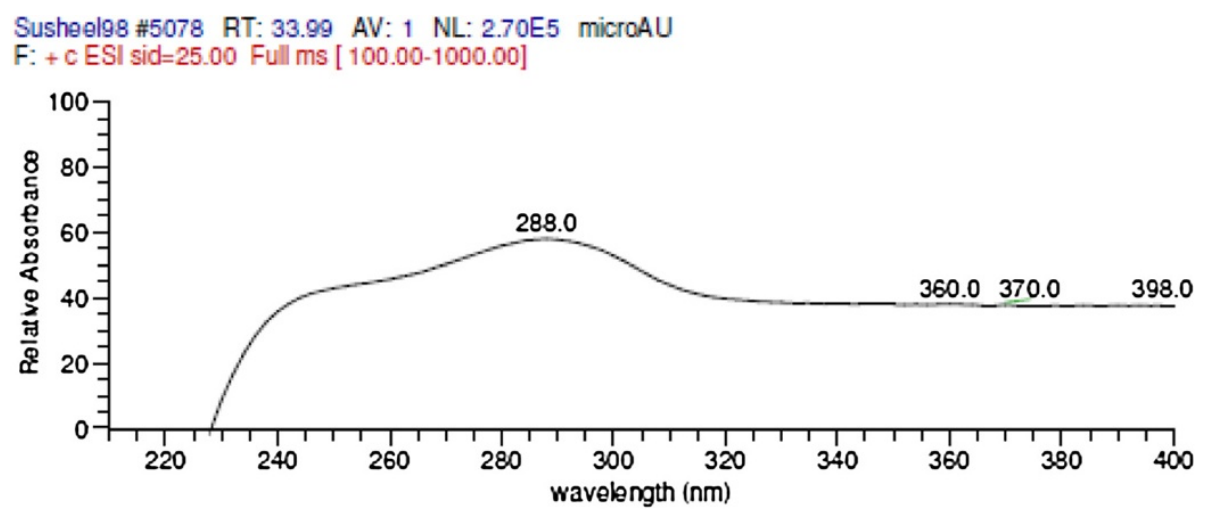

Figure 5 UV spectrum of the compound ' $A$ '.

Varian Prepstar 320 detector and Rheodyne 7725i injection block. LC-MS was performed on Agilent 1100 series HPLC system (pump, detector and autosampler) with Knauer (125 mm L, $2 \mathrm{~mm}$ ID), prepacked with Eurosphere- $100 \mathrm{C}-18(5 \mu \mathrm{m})$ and with integrated precolumn and Finnigan LC Q-DECA MS detector. HPLC grade methanol and nanopure water with ortho-phosphoric acid $0.15 \%$, pH 2.0 were used for HPLC and LCMS. ${ }^{1} \mathrm{H}$ NMR was recorded on Bruker DRX-500 instrument operating at $500 \mathrm{MHz}$.
Batch culture fermentation of C. globosum EF18 and its extraction

Fungus was multiplied in 11.7 litres of wickerham medium [Malt extract $(3 \mathrm{~g} / \mathrm{l})$; Yeast extract $(3 \mathrm{~g} / \mathrm{l})$; Peptone $(5 \mathrm{~g} / \mathrm{l}) ;$ Glucose (Qualigens)-10 g/l; pH-7.2-7.4] at $24^{\circ} \mathrm{C}$ for 3-4 weeks. Media chemicals were purchased from Himedia, India. One flask of medium without the inoculum was kept as control. Metabolite extraction was done as per the protocol of Wicklow et al. (1998). Extraction procedure has been depicted in Figure 9 as flow diagram.

Susheel98 \#1208 HI: 33.82 AV: 1 NL: $2.55-7$

T: + c ESI sid $=25.00$ Full ms [ 100.00-1000.00]

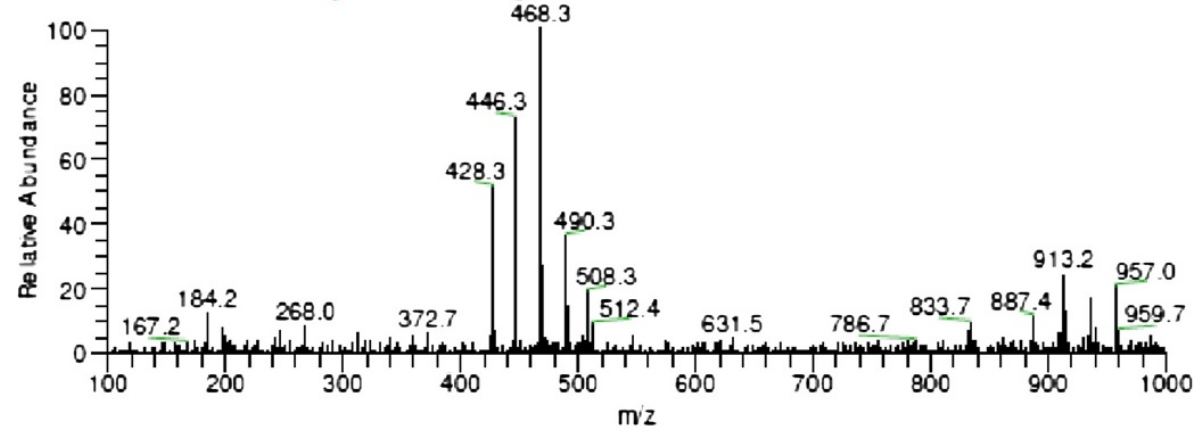

Susheel98 \#1206 RT: 33.78 AV: 1 NL: $2.76 E 7$

T: - c ESI sid $=25.00$ Full $\mathrm{ms}$ [ 100.00-1000.00]

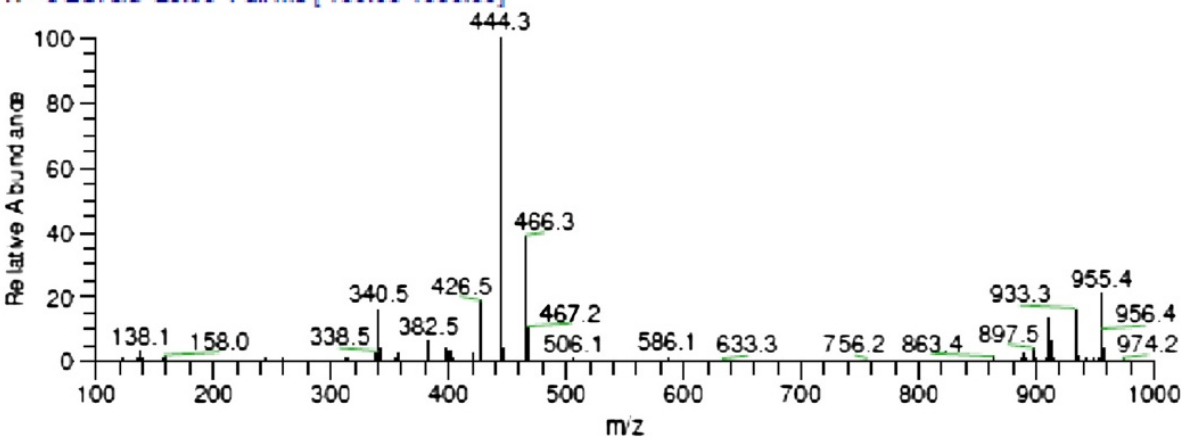

Figure $6 \mathrm{~m} / \mathrm{z}\left(\mathrm{H}^{+}\right)$spectra of the purified compound ' $A$ '. 


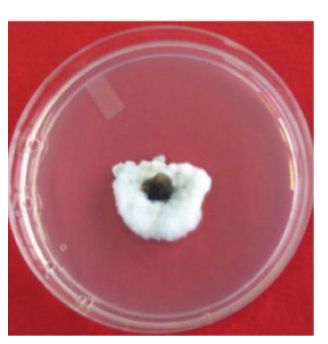

WSL 2E VIII $100 \mu \mathrm{g} / \mathrm{ml}$

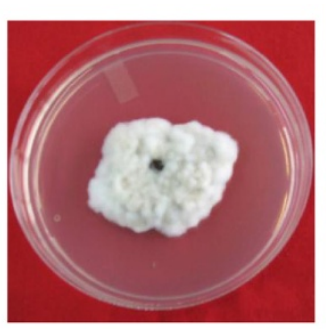

WSL 2E IX $100 \mu \mathrm{g} / \mathrm{ml}$

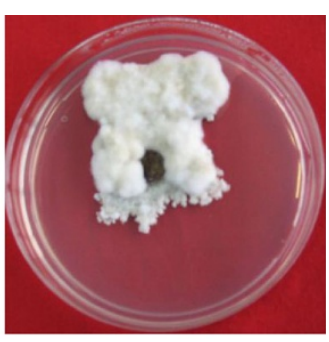

WSL 2E X $100 \mu \mathrm{g} / \mathrm{ml}$

Figure 7 Effect of different VLC fractions obtained from ethyl acetate extract of C. globosum EF18 on radial growth of S. sclerotiorum.

\section{Isolation of antifungal compound}

A schematic diagram of procedure for separation and purification is presented in Figure 10. Extract was subjected to VLC and eluted with dichloromethane: methanol in the following order: 100\% DCM, 95:5 DCM: $\mathrm{MeOH}, 90: 10,80: 20,70: 30,60: 40,50: 50,30: 50,25: 75$ and $100 \% \mathrm{MeOH}$. These fractions (WSL 2E I-X; Figure 10) were dried in rotary under vacuum and investigated by TLC and HPLC. Based on the HPLC and LC-MS profiles of the fractions, fraction no. WSL2E VI was further purified by sephadex LH 20 (Merck) column with dichloromethane and methanol 50:50. Based of TLC pattern, fractions were grouped in to 5 groups- WSL2EVI_I-V. These 5 fractions were analyzed by HPLC and LC-MS. Sub-fraction 1 (WSL2EVI_I) was further purified by sephadex column with $100 \%$ methanol followed by preparative HPLC (Figure 10). Preparative HPLC was done with the following gradient $0-5$ min $50 \%$ methanol and 5-35 min increase from $50-100 \%$ of methanol and from $35-40$ $100 \%$ methanol. One major compound was obtained (compound 'A' in Figure 10).

\section{Identification of antifungal Sch 210971}

The Identification was done by MASS and NMR. The sample was dissolved in methanol and injected to HPLC/

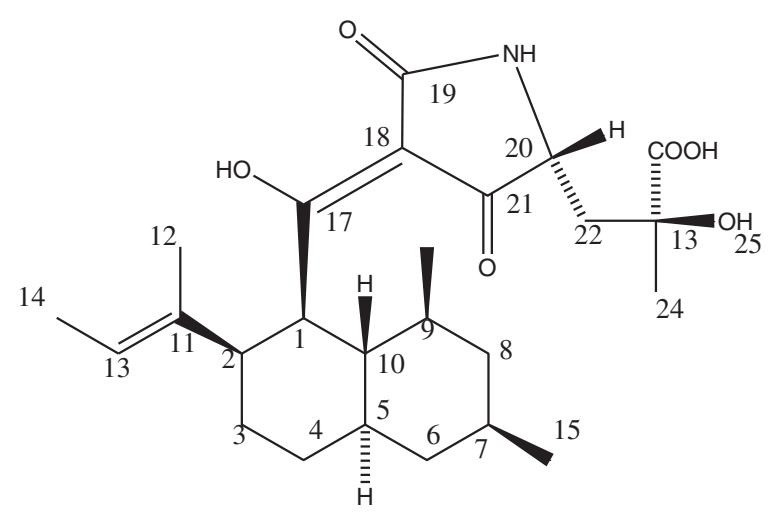

Figure 8 Structure of the antibiotic Sch 210971.
ESI-MS hyphenated system. This compound corresponds to compound of Rt. 42.5 from Waters HPLC, C-18 and to Rt 34.1 from Dionex HPLC. The compound eluted at Rt 33.91 having $\mathrm{m} / \mathrm{z}^{+} 446.3, \lambda_{\max } 288 \mathrm{~nm}$.

NMR measurement carried out at Heinrich Heine Universitat, Dusseldorf, Germany. Deuterated methanol was used to dissolve samples for NMR measurement. 1D and 2D NMR spectra were processed and analyzed using NMR software 1D WIN-NMR and 2D WIN-NMR Bruker NMR suite. NMR spectra were calibrated using solvent signals of their protons. Observed chemical shifts value $(\delta)$ were given in ppm and coupling constant $J$ in hertz $(\mathrm{Hz})$.

${ }^{1} \mathrm{H}$ NMR of the compound 'A' was generated with methanol-d at $500 \mathrm{MHz}$ and found as $\delta 5.84(1 \mathrm{H}, \mathrm{S})$, $5.75(1 \mathrm{H}, \mathrm{s}), 5.59(1 \mathrm{H}, \mathrm{s}), 5.48(\mathrm{~s}), 5.24(\mathrm{~s}), 4.38(1 \mathrm{H}, \mathrm{d})$, $4.29(1 \mathrm{H}, \mathrm{dt}, \mathrm{J}=7.6,6.3), 3.81(\mathrm{dd}), 3.62(1 \mathrm{H}, \mathrm{d}), 2.9$ $(1 \mathrm{H}, \mathrm{br} \mathrm{s}), 2.65(1 \mathrm{H}, \mathrm{s}), 2.34(1 \mathrm{H}, \mathrm{d}, \mathrm{J}=12), 2.19(\mathrm{~s}), 2.13$ $(1 \mathrm{H}, \mathrm{d}, \mathrm{J}=12.5), 1.92(3 \mathrm{H}, \mathrm{d}, \mathrm{J}=9.8), 1.74(3 \mathrm{H}, \mathrm{br} \mathrm{s}), 1.61$ $(5 \mathrm{H}, \mathrm{s}), 1.57(\mathrm{~s}), 1.47(6 \mathrm{H}, \mathrm{d}, \mathrm{J}=10.15), 1.4(2 \mathrm{H}, \mathrm{d}$, $\mathrm{J}=12.2), 1.28(\mathrm{~s}), 1.23(\mathrm{~s}), 1.18(\mathrm{~s}), 0.89(5 \mathrm{H}, \mathrm{d}, \mathrm{J}=2.8)$, $0.79(3 \mathrm{H}, \mathrm{d}, \mathrm{J}=4.2)$. Comparative ${ }^{1} \mathrm{H}$ NMR of the purified compound and published compound is provided in Table 5.

\section{Bioassay of extracts/fractions of C. globosum EF18 against Sclerotinia sclerotiorum}

Bioassay of crude extract was done as per the procedure described by Kumar and Kaushik (2013). Whereas, for bioassay of fractions $30 \mathrm{mg}$ of dried extract was dissolved in $600 \mu \mathrm{l}$ of methanol and out of this 60,120 and $300 \mu \mathrm{l}$ were mixed to $30 \mathrm{ml}$ of media for 100,200 and $500 \mu \mathrm{g} / \mathrm{ml}$ concentrations. There were 3 replications for each treatment.

\section{Data analysis}

Percent growth inhibition (GI) and analysis of variance of the GI was performed as described earlier (Kumar and Kaushik 2013). Concentration at which 50\% growth inhibition occurs i.e. $\mathrm{IC}_{50}$ was calculated by probit analysis (Finney 1971) using the software SPSS 17.0. 


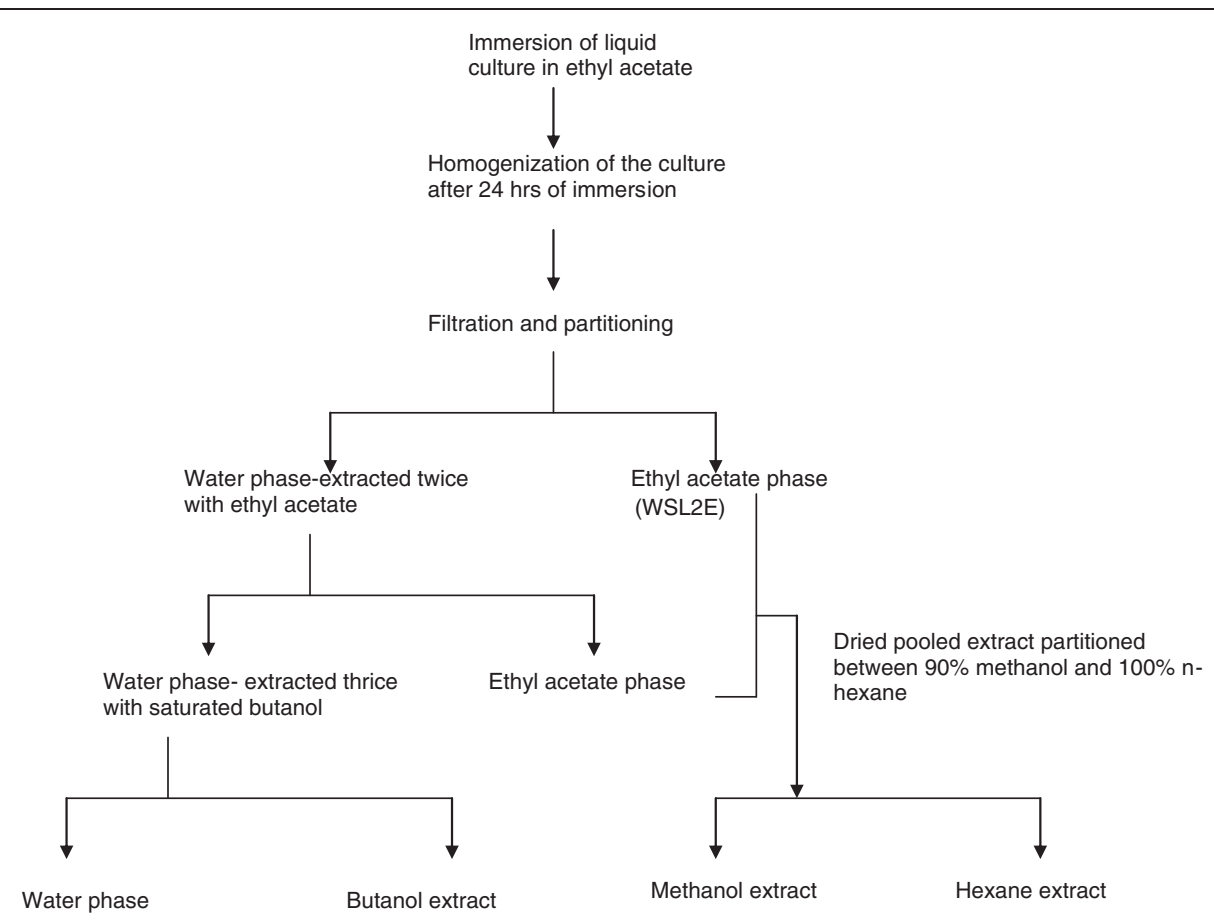

Figure 9 Schematic diagram of extraction procedure for obtaining crude fungal extracts of C. globosum EF18 (WSL2).

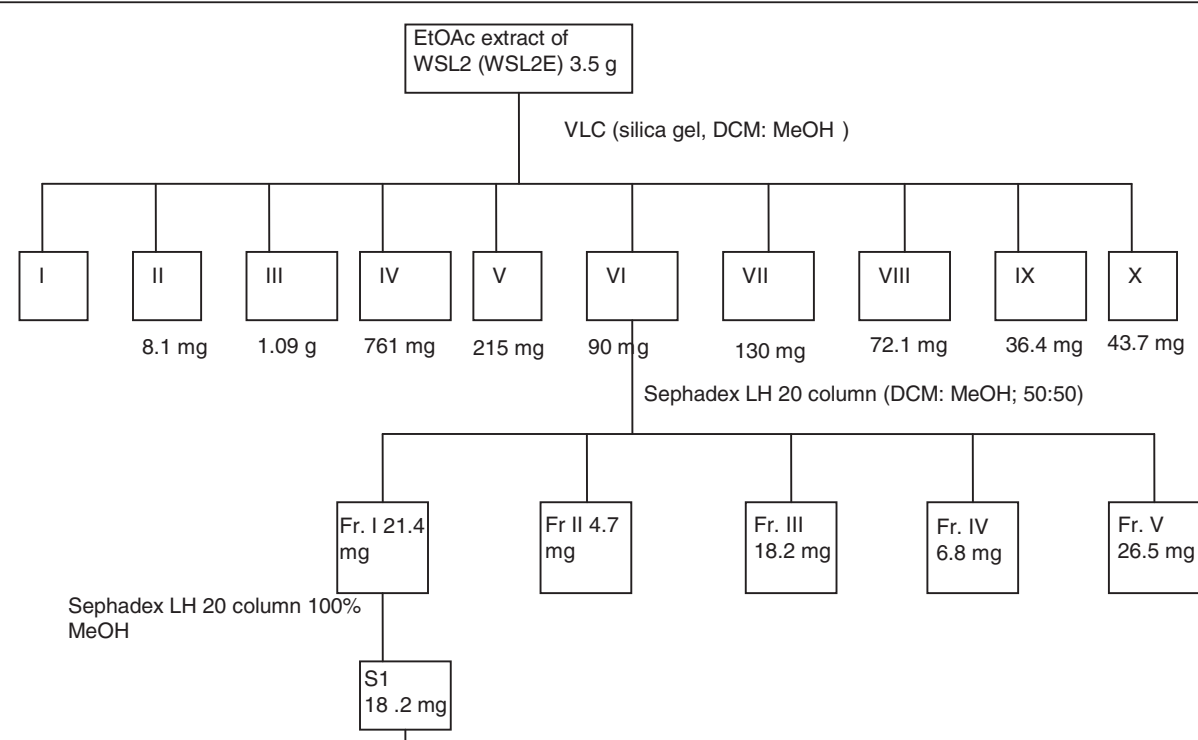

Prep HPLC

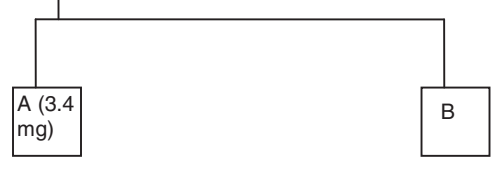

(Antibiotic sch210971)

Figure 10 Schematic diagram of procedure of separation/ purification of ethyl acetate extracts of C. globosum isolate EF18 (WSL2E). 
Table 5 Comparison of ${ }^{1} \mathrm{H}$ NMR of purified fraction and compound ' $A$ ' from literature (Yang et al. 2006)

\begin{tabular}{|c|c|c|c|c|c|c|}
\hline \multirow[t]{2}{*}{ Atom no. } & \multicolumn{2}{|c|}{ Chemical shift $\mathrm{H}^{\prime}$} & \multicolumn{2}{|l|}{ Multiplicity } & \multicolumn{2}{|c|}{ Coupling constant } \\
\hline & Compound ' $A$ ' & Literature & Compound 'A' & Literature & Compound ' $A$ ' & Literature \\
\hline $8 b$ & & 0.83 & & $\mathrm{M}, 1 \mathrm{H}$ & & \\
\hline 16 & 0.79 & 0.85 & D $3 \mathrm{H}$ & $\mathrm{D}, 3 \mathrm{H}$ & 4.2 & 6.5 \\
\hline 15 & 0.89 & 0.91 & D $5 \mathrm{H}$ & $\mathrm{D}, 3 \mathrm{H}$ & 2.8 & 6.5 \\
\hline \multirow[t]{4}{*}{$6 \mathrm{~b}$} & & 0.95 & & $\mathrm{M}, 1 \mathrm{H}$ & & \\
\hline & 1.18 & & S & & & \\
\hline & 1.23 & & $\mathrm{~s}$ & & & \\
\hline & 1.28 & & $\mathrm{~s}$ & & & \\
\hline 9 & & 1.39 & & $\mathrm{M}, 1 \mathrm{H}$ & & \\
\hline 10 & 1.4 & 1.4 & D $2 \mathrm{H}$ & $\mathrm{M}, 1 \mathrm{H}$ & 12.2 & \\
\hline 24 & 1.47 & 1.49 & D $6 \mathrm{H}$ & $\mathrm{S}, 3 \mathrm{H}$ & 10.15 & \\
\hline 14 & & 1.5 & & $\mathrm{Brd}, 3 \mathrm{H}$ & & 6.5 \\
\hline 12 & 1.57 & 1.57 & S & $\mathrm{Br} s, 3 \mathrm{H}$ & & \\
\hline 7 & & 1.63 & & $\mathrm{M}, 1 \mathrm{H}$ & & \\
\hline $8 a$ & 1.61 & 1.66 & $\mathrm{~S} 5 \mathrm{H}$ & $\mathrm{M}, 1 \mathrm{H}$ & & \\
\hline $22 \mathrm{~b}$ & 1.74 & 1.75 & BR S $3 \mathrm{H}$ & $\mathrm{Dd}, 2 \mathrm{H}$ & & \\
\hline 5 & & 1.85 & & $\mathrm{M}, 1 \mathrm{H}$ & & \\
\hline \multirow[t]{3}{*}{$6 a$} & 1.92 & 1.91 & D $3 \mathrm{H}$ & $\mathrm{M}, 1 \mathrm{H}$ & 9.8 & \\
\hline & 2.13 & & D $1 H$ & & 12.5 & \\
\hline & 2.19 & & s & & & \\
\hline \multirow[t]{2}{*}{$22 a$} & 2.34 & 2.5 & D $1 H$ & $\mathrm{Dd}, 1 \mathrm{H}$ & 12.0 & $14.0,2.5$ \\
\hline & 2.65 & & $\mathrm{~S} 1 \mathrm{H}$ & & & \\
\hline \multirow[t]{2}{*}{2} & 2.9 & 3.00 & BR S $1 \mathrm{H}$ & $\mathrm{Dt}, 1 \mathrm{H}$ & & $8.0,1.0,1.0$ \\
\hline & 3.62 & & $\mathrm{D} 1 \mathrm{H}$ & & 12.45 & \\
\hline 20 & 3.81 & 3.8 & DD & $\mathrm{Dd}, 1 \mathrm{H}$ & & $10.0,2.5$ \\
\hline \multirow[t]{2}{*}{1} & 4.29 & 3.94 & DT $1 \mathrm{H}$ & $\mathrm{Dd}, 1 \mathrm{H}$ & $7.6,6.3$ & $8.0,7.0$ \\
\hline & 4.38 & & $\mathrm{D} 1 \mathrm{H}$ & & & \\
\hline \multirow[t]{2}{*}{13} & 5.24 & 5.19 & s & $\mathrm{Dq}, 1 \mathrm{H}$ & & $6.5,1.0$ \\
\hline & 5.48 & & S & & & \\
\hline 3 & 5.59 & 5.66 & $\mathrm{~S} 1 \mathrm{H}$ & $\mathrm{Brs}, 2 \mathrm{H}$ & & \\
\hline \multirow[t]{2}{*}{4} & 5.75 & & $\mathrm{~S} 1 \mathrm{H}$ & & & \\
\hline & 5.84 & & $\mathrm{~S} 1 \mathrm{H}$ & & & \\
\hline
\end{tabular}

\section{Competing interests}

The authors declare that they have no competing interests.

\section{Authors' contributions}

SK carried out fractionation of crude extract and isolation of metabolite, did bioassay and drafted the manuscript. NK and PP did the interpretation of NMR data of compound and helped in planning of the experiment and corrected the manuscript. All authors read and approved the final manuscript.

\section{Acknowledgements}

We are grateful to DST-DAAD for providing grant for personal exchange to carry out joint research. Susheel Kumar is grateful to University Grant

Commisssion, New Delhi for the fellowship.

\section{Author details}

${ }^{1}$ TERI University, 10 Institutional Area, Vasant Kunj, New Delhi 110 070, India.

${ }^{2}$ The Energy and Resources Institute (TERI), Habitat Center, Lodhi Road,
New Delhi 110003, India. ${ }^{3}$ Institut für Pharmazeutische Biologie und Biotechnologie, Heinrich-Heine-Universität Düsseldorf, Düsseldorf 40225, Germany.

Received: 28 September 2012 Accepted: 29 January 2013 Published: 6 February 2013

\section{References}

Agrios GN (2005) Plant pathology. Elsevier Academic Press, USA.

Boland GJ, Hall R (1994) Index of plant hosts of Sclerotinia sclerotiorum. Can J Plant Pathol 16:93-100

Di-Pietro A, Gut-Rella M, Pachlatka JP, Schwinn FJ (1992) Role of antibiotics produced by Chaetomium globosum in biocontrol of Pythium ultimum, a causal agent of damping off. Phytopathol 82:131-135

Finney DJ (1971) Probit Analysis, 3rd edition. Cambridge University Press, Cambridge, UK. 1971;ISBN 052108041X. OCLC 174198382 
Inglis GD, Kawchuk LM (2002) Comparative degradation of oomycete, ascomycete, and basidiomycete cell walls by mycoparasitic and biocontrol fungi. Can J Microbiol 48:60-70

Kumar S, Kaushik N (2013) Endophytic fungi isolated from oil-seed crop Jatropha curcas produces oil and exhibit antifungal activity. PLoS ONE 8: e56202. doi:10.1371/journal.pone.0056202

Kumar S, Kaushik N, Edrada-Ebel R, Ebel R, Proksch P (2008) Endophytic fungi for pest and disease management. In: Ciancio A, Mukerji KG (ed) Integrated Management of Diseases Caused by Fungi, Phytoplasma and Bacteria. Integrated Management of Plant Pests and Diseases, vol 3. Springer, Netherlands, pp 365-387. doi:10.1007/978-1-4020-8571-0_17

Montesinos E (2003) Development, registration and commercialization of microbial pesticides for plant protection. Int Microbiol 6:245-252

Nakashina N, Moromizato Z, Matsuyama N (1991) The antifungal substance produced by Chaetomium trilaterale var. diporum RC-5 isolated from sclerotia of Sclerotinia sclerotiorum. Ann Phytopath Soc Japan 57:657-662

Park J-H, Gyung JC, Kyoung SJ, He KL, Heung TK, Kwang YC, Kim J-C (2005) Antifungal activity against plant pathogenic fungi of chaetoviridins isolated from Chaetomium globosum. FEMS Microbiol Lett 252:309-313

Purdy LH (1979) Sclerotinia sclerotiorum: history, diseases and symptomatology, host range, geographic distribution, and impact. Phytopathology 69:875-880

Qin J-C, Zhang Y-M, Gao J-M, Bai M-S, Yang S-X, Laatsch H, Zhang A-L (2009) Bioactive metabolites produced by Chaetomium globosum, an endophytic fungus isolated from Ginkgo biloba. Bio Med Chemi Lett 19:1572-1574

Soytong K, Kanokmedhakul S, Kukongviriyapa V, Isobe M (2001) Application of Chaetomium sp (Ketomium ${ }^{\circledR}$ ) as a new broad-spectrum biological fungicide for plant disease control: a review article. Fungal Diversity 7:1-15

Wang Y, Xu L, Ren W, Zhao D, Zhu Y, Wu X (2012) Bioactive metabolites from Chaetomium globosum L18, an endophytic fungus in the medicinal plant Curcuma wenyujin. Phytomedicine 19:364-368

Wicklow DT, Joshi BK, Gamble WR, Gloer JB, Dowd PF (1998) Antifungal metabolites (Monorden, Monocillin IV, and Cerebrosides) from Humicola fuscoatra Traaen NRRL 22980, a mycoparasite of Aspergillus flavus sclerotia. Appl Environ Microbiol 64:4482-4484

Wrather JA, Koenning SR (2006) Estimates of disease effects on soybean yields in the United States 2003 to 2005. J Nematol 38:173-180

Yang S-W, Mierzwa R, Terracciano J, Patel M, Gullo V, Wagner N, Baroudy B, Puar M, Chan T-M, McPhail AT, Chu M (2006) Chemokine receptor CCR-5 inhibitors produced by Chaetomium globosum. J Nat Prod 69:1025-1028

Zhang G, Wang F, Qin J, Wang D, Zhang J, Zhang Y, Zhang S, Pan H (2013) Efficacy assessment of antifungal metabolites from Chaetomium globosum No. 05, a new biocontrol agent against Setosphaeria turcica. Biol Control 64:90-98

doi:10.1186/2193-1801-2-37

Cite this article as: Kumar et al:: Identification of antifungal principle in the solvent extract of an endophytic fungus Chaetomium globosum from Withania somnifera. SpringerPlus 2013 2:37.

\section{Submit your manuscript to a SpringerOpen ${ }^{\circ}$ journal and benefit from:}

- Convenient online submission

- Rigorous peer review

- Immediate publication on acceptance

- Open access: articles freely available online

- High visibility within the field

- Retaining the copyright to your article

Submit your next manuscript at $\gg$ springeropen.com 